\title{
Imminent extinction crisis among the endemic species of the forests of Yanbaru, Okinawa, Japan
}

\author{
Yosiaki Itô, Kuniharu Miyagi and Hidetoshi Ota
}

\begin{abstract}
The natural forest in Yanbaru, the northern part of the main island of Okinawa (Okinawa Hontô), is an important area for nature conservation, because it has a large number of endemic animals and plants. First, we explain the status of the most important endemic animals of Yanbaru, stressing that most of them are endangered and near extinction. Second, we show especially high species diversity of trees, insects and mites in the Yanbaru forest. However, the integrity of the Yanbaru forest is seriously threatened by clearcutting and complete removal of forest undergrowth.
\end{abstract}

Although an area in Yanbaru occupied by the US Marine Corps has, to date, preserved good natural forest, a new plan to establish seven military helipads in this area is now being examined. Possible outcomes of such a development are evaluated. In addition, requests by Japanese biologists for the Defence Facilities Administration Agency, Japan to consider alternate sites for the helipads are described.

Keywords Endangered species, endemism, Japan, Okinawan forests, species diversity, Yanbaru.

\section{Introduction}

Yanbaru, the northern montane part of Okinawa Hontô, the largest island $(1202 \mathrm{sq} \mathrm{km})$ of the Ryukyu Archipelago of Japan is an important area from both ecological and aesthetic points of view, because it supports a number of specialized endemic animals and plants (see Appendix).

The climax vegetation of Yanbaru ( $300 \mathrm{sq} \mathrm{km}$ in area) is subtropical rain forest, dominated by the evergreen oak or chinquapin Castanopsis sieboldii with other evergreen broadleaf trees such as Distylium racemosum and Schefflera octophlylla (Plate 1). Although the true virgin forest is restricted to a few small areas because a large part of the forest is subjected to thinning or clear-cutting, forest sections that were thinned or cut $40-$ 50 years ago (chiefly for the reconstruction of houses burned completely or destroyed during the war) have recovered the basic features of the climax community. Following the definition by the Nature Conservation Society of Japan (Anonymous, 1995), we refer to parts

Yosiaki Itô (corresponding author) 2908, Kaguyama 2-chome, Nisshin, Aichi 470-0134, Japan. Tel. \& fax: + 81528050437 ; e-mail: itoyos@sam.hi-ho.ne.jp

Kuniharu Miyagi Faculty of Arts and Sciences, Okinawa International University, Ginowan, Okinawa 901-2701, Japan. Tel. \& fax: +8198892 1111; e-mail: kmiyagi@okiu.ac.jp

Hidetoshi Ota Faculty of Science, University of the Ryukyus, Nishihara, Okinawa 903-0213, Japan. Tel: + 81988958937 ; fax: + 8198895 8576; e-mail: ota@sci.u-ryukyu.ac.jp

Revised manuscript accepted for publication 5 June 2000 of the Yanbaru forest dominated by $C$. sieboldii trees older than 30 years as natural forests, and to those including some pine trees Pinus luchuensis as secondary forests (pine trees cannot survive in the climax forest of Okinawa) (Tsuchiya \& Miyagi, 1991; see also Yokota, 1994 for English explanation).

Most of the characteristic Okinawan wildlife, including mammals and birds endemic to this island, can breed only in natural forests. However, except for the forests located in the US Marine Corps Northern Training Area (NTA, hereafter), which occupies $c .25$ per cent of the Yanbaru on the eastern slope of the central montane area (Fig. 1), the natural forests of Yanbaru are now being destroyed by clear-cutting and complete removal of undergrowth by national and prefectural governments. Thus, extensive areas of natural forest now remain in the NTA only (Fig. 1).

A new problem, however, arose in 1999. In response to a request from the Marine Corps, the Defence Facilities Administration Agency (DFAA) of Japan is now planning to establish seven helipads within two of the best preserved natural forest areas in the NTA (see Fig. 1). One of the main reasons for the publication of this article is to highlight the biodiversity of the sites that are planned for development.

\section{Endangered animal species}

The Appendix shows a list of species and subspecies of terrestrial vertebrates living on Okinawa Hontô, including their distribution characteristics and status according to the revised Red Lists of the Environmental Agency of Japan (Anon., 1997, 1998). Although 
there are some endangered species in the sea around Yanbaru (e.g. Dugong dugong), we discuss hereafter terrestrial vertebrates only. High proportions of species or subspecies that are endemic to Okinawa Hontô (including some species which are endemic to Yanbaru) or endemic to the Amami Islands and Okinawa Islands (N-MR) are notable (69 percent of mammals, 74 per cent of reptiles and 75 per cent of amphibians). Migratory species, stragglers, and species belonging to groups that live on the seashore, around rivers or ponds, crags and buildings were omitted from the list of birds. Nevertheless, of the 22 species found in the forests of Yanbaru, two species and one subspecies are unique to Yanbaru, and 17 are subspecies that are endemic to the Ryukyu Archipelago.

Table 1 shows the numbers of Critically Endangered (CE), Endangered (E) and Vulnerable (V) species of terrestrial vertebrates living in Yanbaru, as compared with the numbers in the whole of Japan. Yanbaru has a notably large proportion of threatened vertebrate species, despite its small area (c. 0.08 per cent of the total area of Japan). For example, Yanbaru has 2 (16.7 per cent) of $12 \mathrm{CE}$ species and 4 (20 per cent) of 20 $\mathrm{E}$ species of mammals living in Japan.

In addition, it is worth noting that 5 of the $11 \mathrm{CE}$ and E species of 4 tetrapod classes, shown in the Appendix, are endemic to Yanbaru only, and the other 6 species are endemic to the Ryukyu Archipelago. Even for the latter, extinction of the Yanbaru population may induce a high risk of complete extinction of these species from the earth, because populations living in the other islands (especially Amami-Oshima Islands and Tokunoshima Islands) seem to be smaller than those in Yanbaru.

In the revised Red Lists of Japan, only a part of which have been published to date, the Environmental Agency is using three subcategories of the category 'Threatened', namely CE, E and V (see explanation in Anon., 1997, 1998), similar to the new IUCN Red Lists (IUCN, 1999). However, due to the lack of good quantitative data on the current population size and rate of recent population declines in many species, the

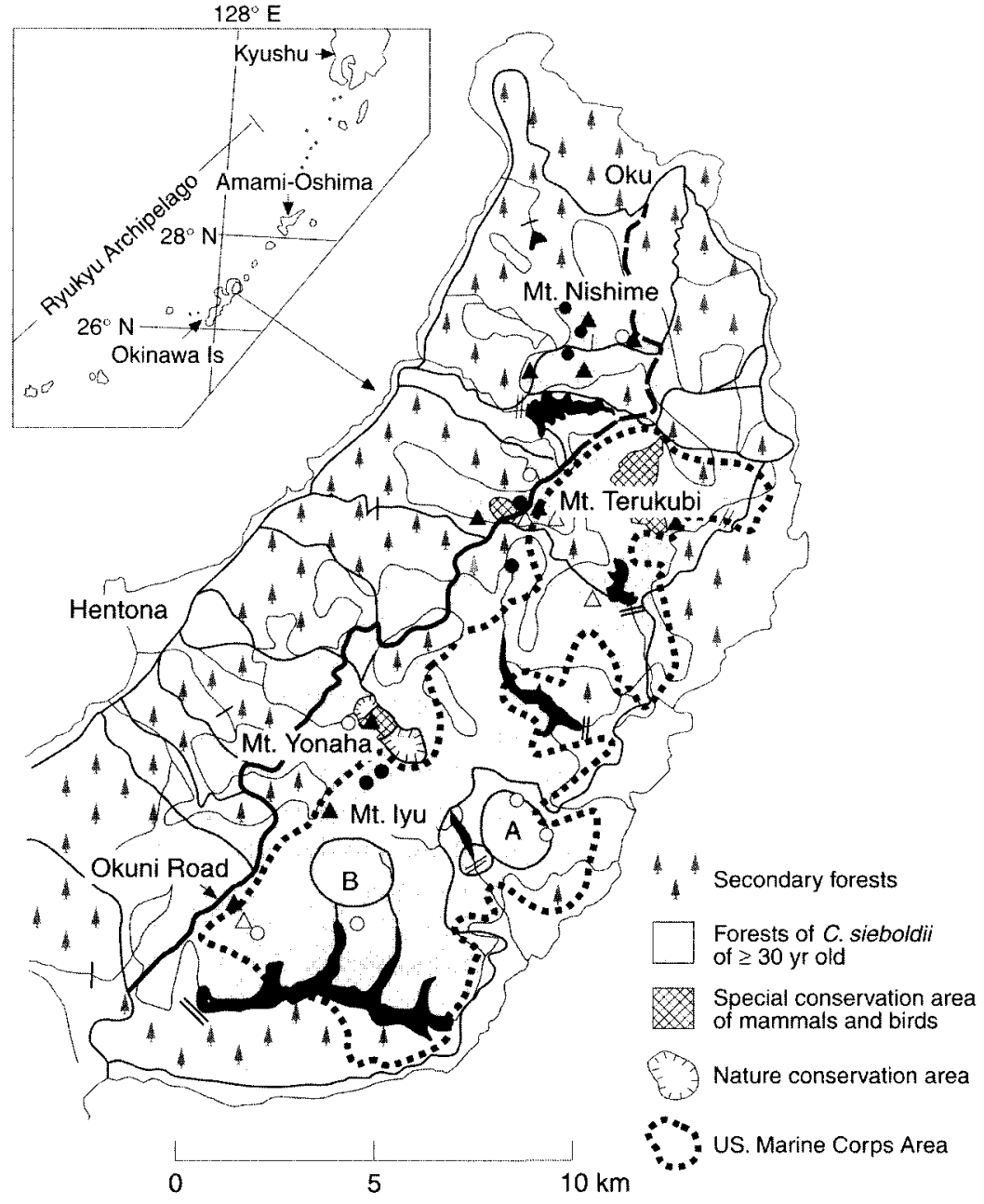

Fig. 1 Map of Yanbaru, showing natural forests, US Marine Corps Northern Training Area (NTA) and areas proposed for establishment of Marine Corps helipads (A and $B$ ). 
Table 1 Number of Critically Endangered and Endangered species, living in the whole of Japan and Yanbaru, described in the new Red Lists of the Environmental Agency of Japan (Anon., 1997, 1998)

\begin{tabular}{llrrrl}
\hline Category & Area & Mammals & Birds & Reptiles & Amphibians \\
\hline Critically Endangered & Whole of Japan & 12 & 17 & 2 & 1 \\
& Yanbaru & 2 & 1 & 0 & 0 \\
Endangered & Whole of Japan & 20 & 25 & 5 & 4 \\
\multirow{3}{*}{ Vulnerable } & Yanbaru & 4 & 2 & 0 & 1 \\
& Whole of Japan & 16 & 48 & 11 & 9 \\
& Yanbaru & 0 & 2 & 2 & 4 \\
\hline
\end{tabular}

categorical designations in the Japanese Red Lists are not sufficient to satisfy the conditions necessary to define the status of a species according to the IUCN categories. In addition, the Environmental Agency uses subspecies in the Red List of Japan. For example, Tokudain osimensis osimensis from Amami-Oshima and Tokunoshima Islands and T. o. mueninki from Yanbaru are listed as two independent Threatened species (although some Japanese mammalogists consider that the Yanbaru population belongs to a separate species, $T$. muleninki, different from T. osimensis: Abe et al., 1994).

Nevertheless, at least for the mammals and birds of Yanbaru, the CE and E categories of the new Red Lists of Japan are almost equivalent to those of the IUCN. As discussed below, the numbers of living individuals of three CE species listed in the Appendix are believed to be fewer than 1000 and those of six E species of mammals and birds are fewer than 3000 (of which two species are possibly represented by fewer than 1000 individuals; see below). The Yanbaru whiskered bat Myotis yanbarensis was newly discovered in the NTA in 1997 (Maeda \& Matsumura, 1998), and since then only three individuals, including the two specimens used for the description, have been found from a small area $(\mathrm{K}$. Maeda, pers. comm.). In recent years, only two dead individuals of the Okinawa spiny rat $T$. osimensis mueninki (Plate 2) have been found and only one living individual was photographed by an ultravioletactivated camera, although spinous hairs of this species were found recently in the faeces of feral cats (Yambaru Chapter, Wild Bird Society of Japan, 1997). According to Azama (1996), the number of Noguchi's woodpecker (or Pryer's woodpecker Sapheopipo noguchii) adults (Plate 4) in 1992 was estimated to be between 400 and 500 (based on counts of nest holes and the identification of adults after hearing their territorial song induced by playback of recorded birdsong).

Among E species, the Ryukyu tube-nosed bat Murina ryukyuana (Plate 2) was also discovered in the NTA in 1997 (Maeda \& Matsumura, 1998). Since then, only about 10 living animals have been detected from an area of c. $100 \mathrm{sq} \mathrm{km} \mathrm{(K.} \mathrm{Maeda} \mathrm{and} \mathrm{S.} \mathrm{Matsumura,} \mathrm{pers.}$ comm.). A living individual and a dead individual of the Ryukyu long-haired rat Diplothrix legata (Plate 2) were found in 1999; these are the only specimens that have been found in the last 5 years. Thus, the mean numbers of individuals of these two species in recent years are believed to be fewer than 1000. Although quantitative data are not available, numbers of living individuals of other E species in Yanbaru, such as the Okinawan rail Gallirallus okinawae (Plate 3), are not believed to exceed 10,000 .

As far as invertebrates are concerned, the giant longarmed scarab beetle Cheirotonus jambar (Plate 3 ) is at risk because it may be close to extinction. Its larvae can grow only by feeding on the humus that accumulates in large holes on large trees (i.e. stem diameter of breast height, DBH, $\geq 40 \mathrm{~cm}$ : Azuma et al., 1985, 1986; Azuma, 1994), but a few large trees only remain in areas outside the NTA due to clear-cutting, and these trees are often checked by poachers who sell beetles illegally; the giant long-armed scarab beetle is a special national emblem of Japan. Egg size ( $6 \mathrm{~mm}$ diameter) of C. jambar is exceptionally large among insects, females lay only about 20 eggs during their lives, and the larval period is 3-4 years (Azuma et al., 1985, 1986). The mean number of adults that emerge each year is possibly fewer than 1000 (S. Azuma, pers. comm.).

\section{Biodiversity in Yanbaru forests}

Table 2 shows the numbers of species of some groups of animals and plants in Yanbaru relative to those in the whole of Japan and Hokkaido, the northernmost main island of Japan. It can be seen that Yanbaru has a remarkably large number of species. Of Japan's native fauna and flora, around 8 percent of mammals, 40 per cent of ants and c. 25 per cent each of reptiles, anurans, cicadas and vascular plants are found on Yanbaru.

Twenty-two species of resident birds are known to breed in the forest of Yanbaru (Appendix; species that live in Yanbaru but that breed on the seashore, in cultivated fields and buildings, for example, Passer montanus, are excluded). Of these, two (Sapheopipo noguchii and Gallirallus okinawae) are endemic to this area, and two (Accipiter gularis and Scolopax mira) are endemic to the Ryukyu Archipelago at the full-species level. Of the remainder, 17 are endemic to the Ryukyu Archipelago at the subspecies level, whereas the other, 


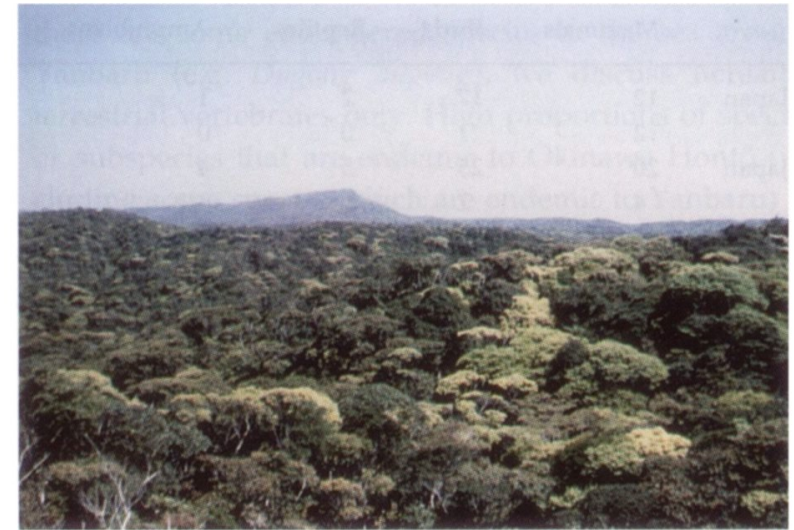

Plate 1 Forest of Yanbaru, dominated by the evergreen oak, Castanopsis sieboldii $(Y$. Itô).
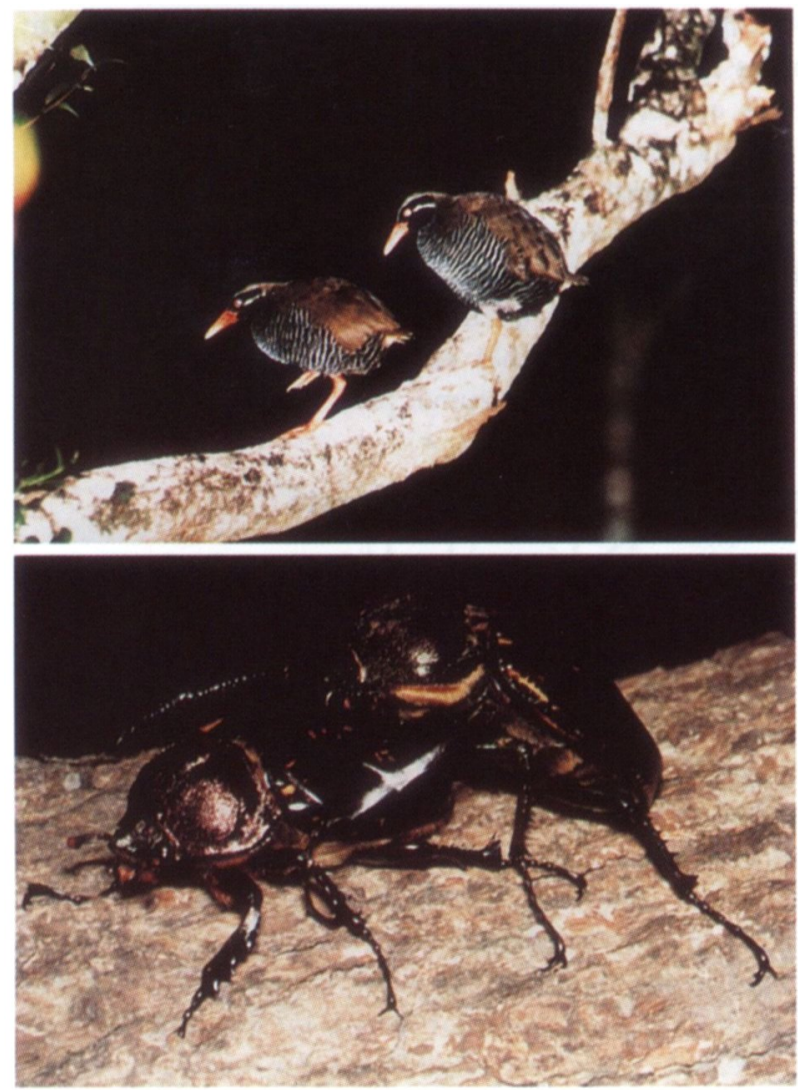

Plate 3 Top: The Okinawan rail Gallirallus okinazue is a flightless rail, also strictly endemic to Yanbaru ( $C$. Tamaki ). Bottom: The giant long-armed beetle Cheirotonus jambar is strictiy endemic to Yanbaru. This species is considered to be most at risk of extinction ( $T$. Sasaki).
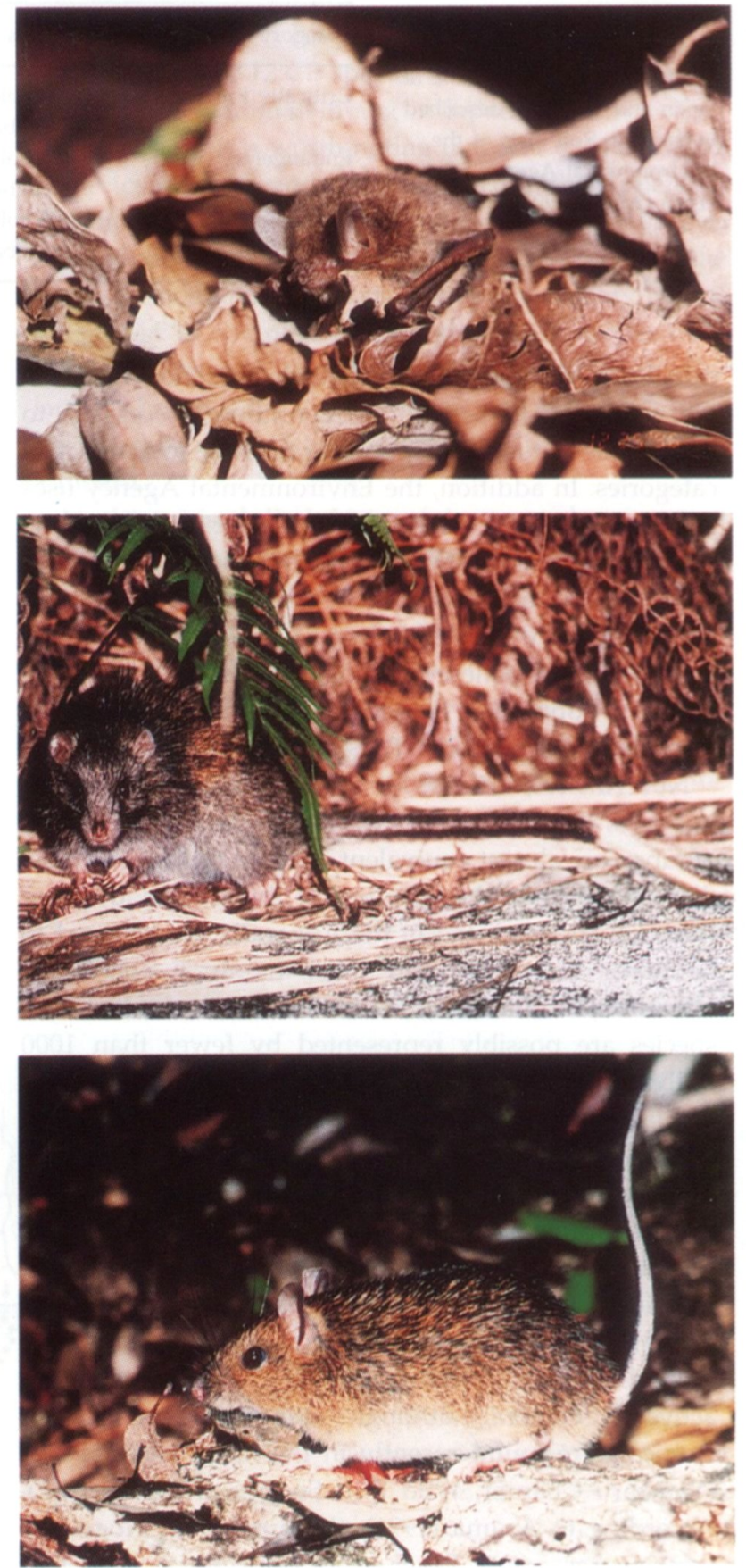

Plate 2 Top: The Ryukyu tube-nose bat Murino ryıky/uma discovered in 1997 (K. Maeda). Only about 10 individuals have been found to date, despite 3 years of extensive searching following the discovery of the species. Middle: The Ryukyu long-haired rat Diplothrix legatn, the largest rat in Japan ( $M$. Kudaka). Endemic to Yanbaru, Amami-Oshima Island and Tokunoshima Island. Only one dead and one living individual have been found in Yanbaru since 1995, despite extensive searching. Bottom: The Okinawa spiny rat Tokudnin osimensis mueninki (M. Kudaka). Although T. o. osimensis is found on Amami-Oshima Island and Tokunoshima Island, some believe that the Okinawa spiny rat is an independent species, $T$. mueninki. Only three individuals (two dead and one photograph of a living rat) have been found in Yanbaru in recent years. 
Columba janthina janthina, is seen in both the Ryukyu Archipelago and the main islands of Japan (Hanawa, 1998).

Many indices have been proposed to measure species diversity, including species richness and heterogeneity of numbers of individuals among species in a community.

For the purposes of this paper, we use two non-parametric species diversity indices, $1 / D$ and $1-D$, where $D$ is Simpson's index (Simpson, 1949):

$D=\sum \frac{n_{i}\left(n_{i}-1\right)}{N(N-1)^{\prime}}$

and $n_{i}$ and $N$ are the number of individuals of $i$ th species and total number of individuals, respectively.

We also use the equitability index suggested by Pielou (1969):

$J^{\prime}=H^{\prime} / H_{\text {max }}^{\prime}$, where $H^{\prime}$ is Shannon-Weaver index or MacArthur's diversity (MacArthur, 1955):

$H^{\prime}=-\Sigma\left(n_{i} / N \log _{2} n_{i} / N\right)$ and $H_{\max }^{\prime}$ is $\log _{2} S$ ( $S$ is the number of species).

Larger vlaues of $1 / D$ and $1-D$ indicate high species diversity (for $1-D$, the maximum value is 1 ), and a larger value of $J^{\prime}$ shows evenness of the numbers of individuals of species in a community (when $J^{\prime}=1$, individual numbers of all species are the same). Lande (1996) recommends the use of $1-D$, but we also apply $1 / D$ and the equitability index because they are frequently used by other researchers.

Table 3 shows the number of species, total number of individuals, and species diversity indices calculated for the following groups of plants and of animals living in Yanbaru: trees $(\mathrm{DBH}>4.5 \mathrm{~cm})$, insects living in the underlayer of forests; ants; and oribatid mites living in soil. (For methods of sampling insects, ants and mites, see Azuma et al., 1997; Itô et al., 1998; Itô \& Aoki, 1999, respectively.)

As shown here, the diversity of tree species in the natural forests of Yanbaru is much higher than that of the deciduous broadleaf forests of Hokkaido, and higher than the evergreen broadleaf forests of Kyushu. In the forests of both Yanbaru and Kyushu, the dominant tree is C. sieboldii. Table 3 also demonstrates that tree species diversity of the secondary forests $(<$ 20 years old) of Yanbaru is lower than that of natural forests. Tree species diversity of the forests of Yanbaru is possibly the highest among Japanese forests. In subarctic and cool-temperate forests, tree species diversity increases during the early stage of succession but decreases in the subsequent stage (e.g. in Hokkaido, the diversity decreases from the broadleaf deciduous forest to the climax sub-arctic coniferous forest). In contrast, 
Table 3 Number of species $(S)$, total number of individuals $(N)$, and species diversity indices $\left(1 / D, 1-D, H^{\prime}\right.$ and $\left.J^{\prime}\right)$ of some groups of plants and animals in Yanbaru and other places. Mean \pm SD is given for data of three or more samples. Values for Hokkaido and Kyushu were calculated using data from published articles (see 'Source').

DBH: diameter at breast height. 'Eberg. brl.' and 'Decid. brl.' denote evergreen broadleaf forest and deciduous broadleaf forest, respectively. All forests in Yanbaru, which are not described in this column, are evergreen broadleaf forests. Regarding Insects, Ants and Oribatid mites, 'natural' refers to natural evergreen forests while 'no u.g.' refers to forests from which the undergrowth was completely cut and removed (see text)

\begin{tabular}{|c|c|c|c|c|c|c|c|c|}
\hline Group and area & $S$ & $N$ & $1 / D$ & $1-D$ & $H^{\prime}$ & $J^{\prime}$ & Note & Source \\
\hline \multicolumn{9}{|c|}{ Trees $(\mathrm{DBH}>4.5 \mathrm{~cm})$. Surveyed area: 4 acres in Yanbaru and Kyushu, 5 acres in Hokkaido } \\
\hline $\begin{array}{l}\text { Yanbaru natural forests } \\
(>50 \text { years old })\end{array}$ & $29.4 \pm 2.5$ & $149 \pm 26$ & $12.6 \pm 1.3$ & $0.92 \pm 0.01$ & 3.66 & $0.83 \pm 0.05$ & Everg. brl. & ltô, $1997 \mathrm{~b}$ \\
\hline $\begin{array}{l}\text { Yanbaru secondary } \\
\text { forests }(<20 \text { years old })\end{array}$ & $23.7 \pm 10.4$ & $191 \pm 92$ & $6.57 \pm 3.0$ & $0.83 \pm 0.07$ & 3.31 & $0.73 \pm 0.11$ & Everg. brl. & Itô, $1997 \mathrm{~b}$ \\
\hline Hokkaido & 5 & 80.5 & 3.03 & 0.34 & 0.96 & 0.43 & Decid. brl. & $\begin{array}{l}\text { Tatewaki \& } \\
\text { Igarashi, } 1971\end{array}$ \\
\hline Kyushu & $12.8 \pm 2.4$ & $181 \pm 4$ & $4.76 \pm 2.0$ & $0.79 \pm 0.10$ & 2.85 & $0.76 \pm 0.12$ & Everg.brl. & Omura et al., 1969 \\
\hline \multicolumn{9}{|c|}{$\begin{array}{l}\text { Insects (sweep net survey, total of } 45 \mathrm{~min} \text { by three people and three sites; } \\
\text { numbers of Lepidoptera, Hymenoptera Diptera are excluded) }\end{array}$} \\
\hline Yanbaru, natural & $75.7 \pm 3.1$ & $282 \pm 47$ & $16.5 \pm 5.7$ & $0.94 \pm 0.02$ & 5.03 & $0.81 \pm 0.06$ & & Azuma et al., 1997 \\
\hline Yanbaru, no u.g. & $66.7 \pm 4.5$ & $553 \pm 200$ & $7.3 \pm 2.9$ & $0.85 \pm 0.06$ & 4.12 & $0.68 \pm 0.11$ & & Azuma et al., 1997 \\
\hline Iriomote, natural & 58 & 202 & 15.8 & 0.94 & 4.94 & 0.84 & & Azuma, 1974 \\
\hline Iriomote, secondary & 53 & 256 & 6.6 & 0.85 & 4.00 & 0.70 & Everg. brl. & Azuma, 1974 \\
\hline \multicolumn{9}{|c|}{ Ants (nest counts over a period of $30 \mathrm{~min}$ ) } \\
\hline Yanbaru, natural & 14 & 43 & 10.0 & 0.90 & 3.41 & 0.90 & & ltô et al., 1998 \\
\hline Hokkaido & 7 & 183 & 1.50 & 0.33 & 1.08 & 0.39 & Decid. brl. & Itô ef al., 1998 \\
\hline Iriomote & 16 & 46 & 7.29 & 0.86 & 3.35 & 0.83 & Everg. brl. & Itô et al., 1998 \\
\hline \multicolumn{9}{|c|}{ Oribatid mites (Tullgren extraction of three soil samples of $10 \times 10 \times 5 \mathrm{~cm}$ ) } \\
\hline Yanbaru, natural & $38 \pm 8$ & $161 \pm 31$ & $15.0 \pm 5.3$ & $0.93 \pm 0.03$ & 4.38 & $0.84 \pm 0.03$ & & Itô \& Aoki, 1999 \\
\hline Yanbaru, no u.g. & $33 \pm 10$ & $293 \pm 176$ & $9.30 \pm 0.73$ & $0.89 \pm 0.01$ & 3.84 & $0.77 \pm 0.02$ & & Itô \& Aoki, 1999 \\
\hline
\end{tabular}

diversity values increase linearly with forest age from 25 to 55 years in Yanbaru (Itô, 1997b).

The natural forests of Yanbaru show high species diversity of insects (data for 14 orders, excluding Lepidoptera, Diptera and Hymenoptera, were used for this calculation because many specimens of moths and mosquitoes are destroyed in the net during sweeping. In addition, the identification of small parasitoid wasps was difficult due to the incompleteness of taxonomy; see Azuma et al., 1997).

Species diversity of Coleoptera in natural forests of Yanbaru is about the same as that in the natural ( $C$. sieboldii-dominated) forest of Iriomote Island, in southern Ryukyus, and far higher than the secondary forests or pine plantation on the island (for undergrowtheliminated forests in Yanbaru, see below). The species diversity of ants, using data collected by 30 -min counts of nests, also shows a far higher diversity in Yanbaru than in Hokkaido. The species diversity of soil-inhabiting oribatid mites in Yanbaru natural forests is also high.

The values of the indices, however, are not the only important consideration; the characteristics of the species found in the natural forests are important as well. Ants can be divided into eurychoric species, i.e. those having a world-wide geographic distribution - including tramp species living in close association with humans-and stenochoric species, i.e. those with a narrower geographic distribution. Table 4 shows the ratios of stenochoric and Ryukyu-endemic species to all ant species (in this paper, stenochoric species are defined as those endemic to South-east Asia). The results indicate that although the number of species in natural forests of Yanbaru does not differ greatly from that in both the secondary forests and logged areas, the ratio of stenochoric species decreases from about 80 per cent in the natural forests to 60 per cent in the secondary forests and 20 per cent in the logged area of Yanbaru. Similarly, the ratio of species endemic to the Ryukyu Archipelago decreases from more than 20 per cent in natural forests to 0 per cent in logged area.

\section{Destruction of the Yanbaru forests}

Since 1972, when Okinawa was returned to Japan, the natural forests of Yanbaru have been destroyed seriously in two ways: first, by large-scale clear-cutting and, second, undergrowth removal funded by national and prefectural subsidies. 
Table 4 Numbers and percentages (in parentheses) of Source stenochoric species (S) and species endemic to the Ryukyu Archipelago (R) of ants in the Yanbaru area. Yamauchi \& Ogata (1995) is a report of a joint survey by members of the Myrmecological Society of Japan.

\begin{tabular}{lllll}
\hline Source & \multicolumn{2}{l}{ Yamauchi \& Ogata (1995) } & & Itô et al. (1998) \\
\cline { 2 - 4 } \cline { 2 - 4 } & Logged sites & Secondary forests & Natural forests & Natural forests \\
\hline No. species & 21 & 18 & 20 & 32 \\
No. and (per cent) of S & $4(19)$ & $11(61)$ & $16(80)$ & $25(78)$ \\
No. and (per cent) of R & 0 & $2(11)$ & $4(20)$ & $10(31)$ \\
\hline
\end{tabular}

The extent of Yanbaru forests cut during the 13 years from 1979 to 1991 was 2443 ha (Department of Agriculture and Forestry, Okinawa Prefectural Government, 1992). More than 60 per cent of the area cut is in the central part of Yanbaru, and nearly half of all natural forests outside of the NTA were clear-cut. Complete cutting and removal of undergrowth (i.e. tree seedlings, shrubs and herbs lower than 2 or $3 \mathrm{~m}$ above ground) was also carried out under a government subsidy through the 'Natural Forest Improvement Project' (Plate 5). According to a table shown by the Department of Agriculture and Forestry Okinawa Prefectural Government to the Association for Preserving the Yanbaru Mountains, the undergrowth was

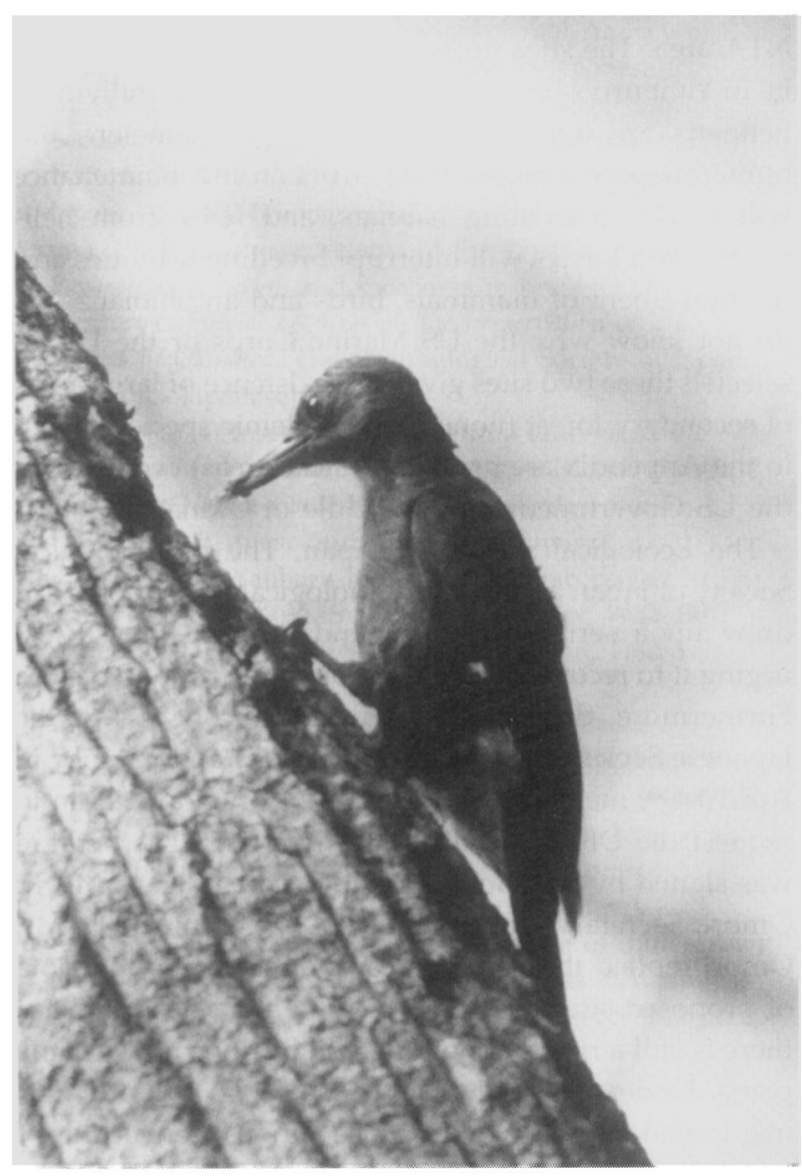

Plate 4 The Noguchi's woodpecker (or Pryer's woodpecker) Sapheopipo noguchii is strictly endemic to Yanbaru (K. Taira). Population size is possibly fewer than 1000 . removed from 3069 ha of the forest over a 21-year period from 1972 to 1992 (Itô, 1995, 1997a). Although this area includes some secondary forests, we estimate that the undergrowth was removed from about half of the 'natural forests'. Despite the recommendation from the Ecological Society of Japan in 1994 and 1995, the Okinawa Prefectural Government still continues with clear-cutting activities and the removal of undergrowth.

Large-scale clear-cutting of the forest deprives it completely of the endemic biota of its natural habitat. Even the removal of undergrowth affects populations of ground animals such as the Okinawa spiny rat $T$. osimensis mueninki, the Ryukyu long-haired rat $D$. legata and the Okinawan rail Gallirallus okinawae. It was observed that larvae of the giant long-armed beetle Cheirotonus jambar died in forests without undergrowth, due to the dryness of humus in holes of remaining large trees (S. Azuma, pers. comm.).

Table 3 shows that the species diversity of insects and mites in 'no undergrowth forests' is always lower than that of intact natural forests. Although the total number of individuals $(N)$ in forests without under-

Table 5 Distribution of oribatid mite species affected by undergrowth removal and those relatively unaffected by it. (n.s.) indicates species described for the first time during our survey

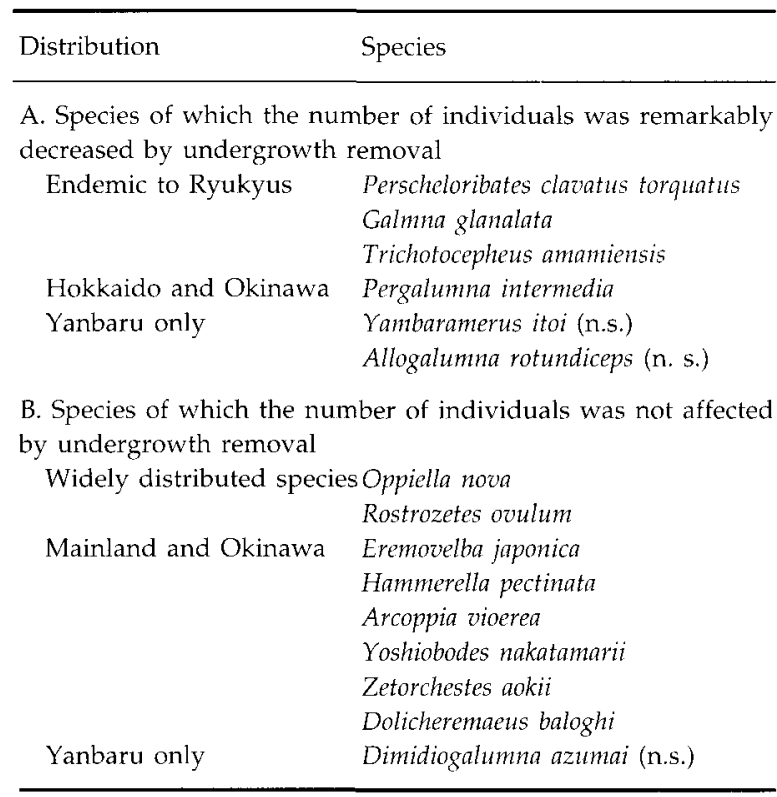



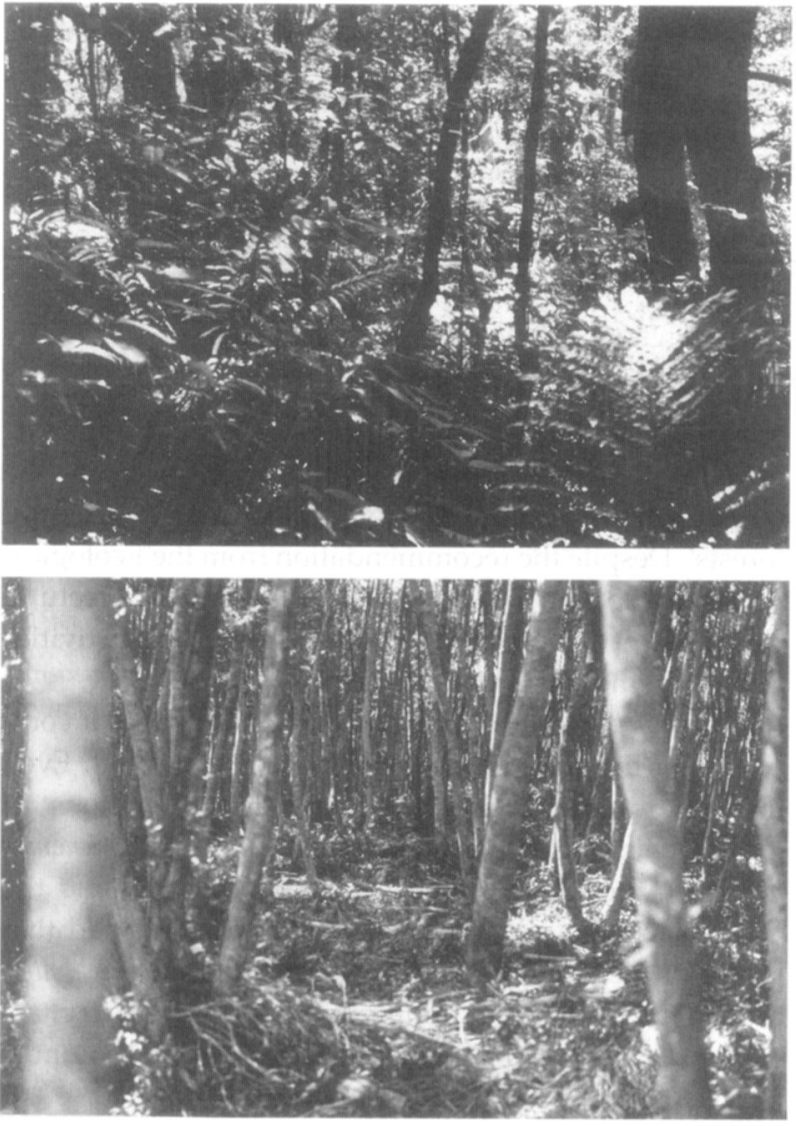

Plate 5 Undergrowth of an intact natural forest (top) and a forest from which undergrowth has been eliminated (bottom; 'no u. g.' in Table 3) in Yanbaru (Y. Itô).

growth is apparently larger than that in the intact forest, this is due to an outbreak of small insects, which are not normal inhabitants of the natural forest but are aliens feeding on rotten logs or herbs, invading into the 'gaps' of forests without undergrowth. Some species of oribatid mites decreased or disappeared from the forests with no undergrowth but this was not the case for other species. Table 5 shows that all of the species affected by the removal of undergrowth (except for Pergalumna intermedia) are known only from the Ryukyu Archipelago or Yanbaru (including two newly-described species), while all those unaffected by undergrowth removal (except for Dimidiogalumna azumai ) are cosmopolitan or widely-distributed species. This finding suggests that many endemic small animals have been seriously damaged by the removal of undergrowth, and some of them might have become extinct already.

Other problems associated with clear-cutting and undergrowth removal are the destruction of 'living reservoirs' (forests) and soil erosion. Chronic water shortage is a major social problem in Okinawa and the government has established many reservoirs in an attempt to address it. Without good natural forests, however, reser- voirs cannot receive a constant supply of water. Heary rainfalls generated by typhoons, which are quite common in Okinawa, may soak through several layers of leaves and accumulate in the soil, which is bound by a high density of roots. Undergrowth removal, however, deprives the watershed of this sponge-like effect. Erosion of soil into the coastal ecosystem kills corals and inhibits their recovery, and no large living coral reef remains around Yanbaru today (Ohmija, 1997). The estuaries of about 80 per cent of rivers in the Yanbaru area have been blocked by the soil and sand (Itô, 1995, 1997a). Although water can pass into the sea through infiltration, diadromous fish and crustaceans, including several endemic species, are thus unable to swim up to rivers or to return to the sea.

During the 20th century, the NTA provided large natural areas for the conservation of biodiversity and endemic species. However, a new problem arose in 1999. According to The Special Action Committee on Okinawa (by the governments of Japan and the USA), the northern portion of the NTA will be returned to Japan. Following a request from the US Government, the DFAA is planning to construct seven helipads in southern part of the NTA area. The sites proposed are shown in Fig. 1; both lie in Yanburu's best natural forest areas. The individual helipads are not very large $(75 \mathrm{~m}$ in diameter), but numerous access roads for construction and maintenance will break up existing habitats, and noise from helicopters and lorries will interrupt breeding activities and the movement of mammals, birds and amphibians. We do not know why the US Marine Corps or the DFAA selected these two sites given the existence of large areas of secondary forest (none of the endemic species shown in the Appendix are present in these areas) occupied by the US Government in the middle of Okinawa Hontô.

The Ecological Society of Japan, The Entomological Society of Japan and The Ornithological Society of Japan drew up a series of recommendations to the DFAA, urging it to reconsider the location of the proposed sites. Furthermore, during the 43rd annual congress of the Japanese Society of Applied Entomology and Zoology in April 1999, members of the Society started a petition to request the DFAA to reconsider its plans. The petition was signed by 677 members and was handed to $\mathrm{Mr}$. K. Omori, Secretary Officer of DFAA, on 9 July 1999. Mr. Omori replied that 'we will carefully consider the biota of proposed sites before making the final decision', but there is still a risk that nothing will be done to revise the plans. Under the 1960 Sikes Act (USA), activities and manipulations that would cause serious destruction of endemic biota in military bases can be halted. We hope that our colleagues in the USA and other countries will support our attempts to mitigate the extinction of a large number of endangered animals and plants in Okinawa. 


\section{Acknowledgements}

We thank S. Azuma, M. Izawa, K. Maeda and S. Matsumura for giving us information on the status of endemic animals, M. Kudaka, K. Maeda, T. Sasaki, K. Taira and $C$. Tamaki for providing photographs, and $K$. $Y$. Kaneshiro and M. Izawa for reading an earlier draft of the manuscript. Thanks are also due to two referees for their helpful comments on the manuscript. A part of the field surveys was supported by the Legacy Project (Study of Biota in the US Marine Corps Northern Training Area) [to KYK and OI] and a grant from the Worldwide Fund for Nature, Japan [to YI].

\section{References}

Abe, H., Ishii, N., Kaneko, Y., Maeda, K., Miura, S. \& Yoneda, M. (1994) A Pictorial Guide to the Mammals of Japon. Tôkai University Press, Tokyo [in Japanese].

Anon. (1995) Forests of Yanbaru. Nature Conservation (Tokyo), Supplement to Volume for 1995 [in Japanese].

Anon. (1997) Revision of Red List of Amphibians and Reptiles. Section of Wild Animals and Plants, Department of Nature Conservation, The Environmental Agency of Japan, Tokyo [Mimeographed copy, in Japanese].

Anon. (1998) Rerision of Red List of Mammals and Birds. Section of Wild Animals and Plants, Department of Nature Conservation, The Environmental Agency of Japan, Tokyo [Mimeographed copy, in Japanese].

Azama, Y. (1996) Present status of the Pryer's woodpecker, Sapheopipo noguchii, and measures to preserve it. Abstract of Special Lectures on the Preservation of Bird Species in Okinazin. The Ornithological Society of Japan, Tokyo [in Japanese].

Azuma, S. (1974) Insect fauna of natural and substitute vegetation at Yaeyama Group, Ryukyu Island. Ecological Studies on Nature Conservation of the Ryukyu Islands, 1, 71-103 [in Japanese with English summary].

Azuma, S. (1994) Yanbaru long-armed scarab beetle. In The For'st of Yambaru (ed. S. Yambaru Chapter, Wild Bird Society of Japan), pp. 98-99, 165. Tôyôkan, Tokyo [English summary].

Azuma, S., Kurosawa, Y. \& Kinjo, M. (1985) Yanbaru Long-armed Scarab Beetle. Survey Report I. Education Council, Okinawa Prefecture, Naha, Japan [in Japanese].

Azuma, S., Kinjo, M. \& Sato, F. (1986) Yanbaru Long-armed Scarab Beetle. Surcey Report II. Education Council, Okinawa Prefecture, Naha, Japan [in Japanese].

Azuma, S., Sasaki, K. \& Itô, Y. (1997) Effects of undergrowth removal on the species diversity of insects in natural forests of Okinawa Hontô. Pacific Conservation Biology, 3, $156-160$.

Department of Agriculture and Forestry, Okinawa Prefectural Government (1992) Transition of Clear-cut Area in the Northern Region of Okinawa Island. Okinawa Prefectural Government, Naha, Japan [in Japanese].

Department of Nature Conservation, Environmental Agency (1991) Research on Indispensable Factors for Conservation of Species of Wild Animals and Plants Living in the
Southwestern Islands of Japan. Environmental Agency, Tokyo [in Japanese].

Environmental Agency of Japan (2000) Threatened Wildlife of Japan: Red Data Book-Reptilia and Amphibia, 2nd edn. Japan Wildlife Research Center, Tokyo [in Japanese with English summary].

Hanawa, S. (1998) Results of surveys of avifauna in Yanbaru, as a teaching material. In Abstracts of Miyake Nature Center 5th Anniversary International Symposium on Ecotourism and Island Birds, 24. Miyake-mura, Tokyo [in Japanese].

Itô, Y. (1995) Forests of Yanbaru, Okinawa: Why Can We Not Conserve its Nature of Outstanding Universal Value? Iwanami Shoten, Tokyo [in Japanese].

Itô, Y. (1997a) Biological explanation: nature and living organisms in Yanbaru, Okinawa. In Okinawa-Yanbart Subtropical Forests: Don't Destroy Treasures of the World (eds K. Taira and Y. Itô), pp. 85-127. Kôbunken, Tokyo [in Japanese].

Itô, Y. (1997b) Diversity of forest tree species in Yanbaru, the northern part of Okinawa Island. Plant Ecology, 133, $125-133$.

Itô, Y. \& Aoki, J. (1999) Species diversity of soil-inhabiting oribatid mites in Yanbaru, the northern part of Okinawa Hontô, and the effects of undergrowth removal on it. Pedobiologia, 43, 110-119.

Itô, Y., Takamine, H. \& Yamauchi, K. (1998) Abundance and species diversity of ants in forests of Yanbaru, the northern part of Okinawa Hontô with special reference to effects of undergrowth removal. Entomological Science, 1, 347-355.

IUCN (1999) The IUCN Red List of Threatened Animals: Database Search Results. IUCN, Gland, Switzerland

Lande, R. (1996) Statistics and partitioning of species diversity, and similarity among multiple communities. Oikos, 76, 5-13.

MacArthur, R.H. (1955) Fluctuation of animal populations and a measure of community stability. Ecology, 36, $533-536$

McWhirter, D.W., Ikenaga, H., Iozawa, H., Shoyama, M. \& Takehara, K. (1996) A check-list of the birds of Okinawa Prefecture with notes on recent satus including hypothetical records. Bulletin of Okinawa Prefectural Museum, 22, 33-152.

Maeda, K. \& Matsumura, S. (1998) Two new species of vespertilionid bats, Myotis and Murina (Vesperetilionidae Chiroptera) from Yanbaru, Okinawa Island, Okinawa Prefecture, Japan. Zoological Science, 15, 301-307.

Maeda, N. \& Matsui, M. (1989) Frogs and Toads of Japan. Bun-ichi Sôgô Shuppan, Tokyo [in Japanese].

Myrmecological Society of Japan (Nippon Ari-rui Kenkyûkai) (1989) Keys and Explanations of Japanese Ants, I Myrmecological Society of Japan. Kodaira, Tokyo [in Japanese].

Myrmecological Society of Japan (1991) Keys and Explanations of Japanese Ants, II Myremecological Society of Japan. Kodaira, Tokyo [in Japanese].

Myrmecological Society of Japan (1992) Keys and Explanations of Japanese Ants, III Myrmecological Society of Japan. Kodaira, Tokyo [in Japanese].

Nakao, S. (1990) Natural History of Cicadas. Chû-ô Kôronsha, Tokyo [in Japanese]. 
Ohmija, T. (1997) Red soil pollution. In To Know the Nature of Okinawa (eds S. Ikehara and Y. Kato), pp. 167-183. Tsukiji Shokan, Tokyo [in Japanese].

Omura, M., Miyata, I. \& Hosokawa, T. (1969) Forest vegetation of Minamata Special Research Area of IBP. Memoires of Faculty of Science, Kyushu University. Series E, Biology, 5, 77-94.

Ornithological Society of Japan (1997) A list of Japanese birds. Japanese Journal of Ornithology, 41, 59-91.

Ota, H. (2000) The current geographic faunal pattern of reptiles and amphibians of the Ryukyu Archipelago and adjacent regions. Tropics, 10, 51-62.

Ota, H. \& Nakagawa, H. (1985) Notes on the specimens of reptiles deposited in Shiretoko Museum, Shari, eastern Hokkaido, Japan. Bulletin of Shiretoko Museum, 7, 1-6 [in Japanese with English summary].

Pielou, E.C. (1969) An Introduction to Mathematical Ecology. Wiley-Interscience, New York.

Shinjo, K. \& Miyagi, Y. (1988) Flora of Kunigami Area of Okinawa Island. In Urgent Research on National Monuments in the Kunigame Area: Research Series of National Monuments of Okianwa Prefecture, No. 30. Education Committee, Okinawa Prefectural Government, pp. 117-193. Naha, Japan [in Japanese].

Simpson, E.H. (1949) Measurement of diversity. Nature, London, 163, 688.

Tatewaki, M. \& Igarashi, T. (1971) Forest vegetation in Teshio-Nakagawa Area of Hokkaido University Forests. Research Reports of University Forests, Hokkaido University, 28, 1-192 [in Japanese with English summary].

Terayama, M. \& Kihara, A. (1994) Distribution Maps of Japanese Ants. Myrmecological Society of Japan. Kodaira, Tokyo [in Japanese].

Tsuchiya, M. \& Miyagi, K. (1991) Observations of Nature on the Southern Islands. Tokai University Press, Tokyo [in Japanese].

Yamauchi, K. \& Ogata, K. (1995) Social structure and reproductive systems of tramp versus endemic ants (Hymenoptera: Formicidae) of the Ryukyu Islands. Pacific Science, 49, 55-68.

Yambaru Chapter, Wild Bird Society of Japan (1997) Status of Valuable and Introduced Animals in the Northern Part of Okinawa Island, and Effects of Introduced Animals on Populations of Valuable Animals. A Report. Yanbaru Chapter, Wild Bird Society of Japan, Kijoka, Okinawa, Japan [in Japanese].

Yokota, M. (1994) The plant life of Yambaru. In The Forest of Yanburu (ed. Yanbaru Chapter of Wild Bird Society of Japan), pp. 153-156. Toyokan, Tokyo.

\section{Biographical sketches}

Yosiaki Itô is a professor emeritus at Nagoya University Nagoya Japan, and former professor at Okinawa University. Much of his research has focused on the population dynamics and social behaviour of insects and insect control by the sterile male technique, but he has recently become involved in conservation biology, especially the conservation of biodiversity in Okinawan biota. He is author of Comparative Ecology (Cambridge University Press) and Behaviour and Social Evolution of Wasps (Oxford University Press).

Kuniharu Miyagi is a professor at the Okinawa Kokusai University, Ginowan, Okinawa. His work focuses on the ecology and conservation of Okinawan birds and mammals.

Hidetsugu Ota is an associate professor at the University of the Ryukyus, Nishihara, Okinawa, and works on the taxonomy and ecology of reptiles and amphibians, with special interest in Okinawa. 


\section{Appendix}

Species of terrestrial Vertebrata living on Okinawa Hontô, including their distribution and categories according to new Red Lists (RDB) (1997 and 1998) of the Environmental Agency, Japan and IUCN.

Only Extinct (EX), Critically Endangered (CE), Endangered (E) and Vulnerable (V) species are shown. IUCN categories are shown in parentheses. Species or subspecies that are endemic to an island or the Yanbaru area are indicated by '(end)' or '(end, subsp.)' in the column entitled 'Distribution \& endemism'. The Yanbaru area in the northern part of Okinawa Hontô is abbreviated to 'Yanb'. For mammals, reptiles and amphibians, all species shown listed as 'R (end)' or ' $\mathrm{N}$-MR (end)', except the Asian common bat, are found in Yanburu. Source of nomenclature: mammals - Abe et al., 1994; birds-McWhirter ot al., 1996; Ornithological Society of Japan, 1997; reptiles - Ota, 2000; amphibians-Ota, 2000.

\begin{tabular}{|c|c|c|}
\hline Species & Distribution \& endemism* & RDB category in Japan (\& IUCN) \\
\hline \multicolumn{3}{|l|}{ Mammals } \\
\hline Watase's shrew Crocidura watasei & N-MR (end) & \\
\hline Ryukyu musk shrew Suncu murinus temnninckii & $R$ (introduced?) & \\
\hline Ryukyu flying-fox Pteropus dasymallus inopinatus & O (end, subsp.) & \\
\hline Okinawa flying-fox Pteropus loochoensis & $\mathrm{O}$ (end) & $\mathrm{EX}(\mathrm{EX})$ \\
\hline Okinawa least horseshore bat Rhinoloplus pumilis & $\mathrm{O}, \mathrm{M}$ (end) & $\mathrm{E}$ \\
\hline Yanbaru whiskered bat Myotis yanbarensis (n.s.)† & Yanb (end) & $\mathrm{CE}$ \\
\hline Asian common bat Pipistrellus abramus & $\mathrm{R}$ & \\
\hline Ryukyu tube-nosed bat Murina ryukyuana (n.s.)† & Yanb (end) & E \\
\hline Rykyu bent-winged bat Miniopterus fuscus & $\mathrm{A}, \mathrm{T}, \mathrm{O}, \mathrm{Y}(\mathrm{end})$ & $\mathrm{E}$ \\
\hline Okinawa spiny rat Tokudaia osimensis mueninki & Yanb (end, subsp.) & $\mathrm{CE}(\mathrm{E})$ \\
\hline Ryukyu long-haired rat Diplothrix legatn & A, T, Yanb (end) & E \\
\hline Ryukyu mouse Mus caroli & $\mathrm{O}$ & \\
\hline Okinawan wild boar Sus scrofi riukituanus & $\mathrm{R}$ & \\
\hline
\end{tabular}

Birds (species breeding in forests and woods of Yanbaru are shown. Winter visitors, migrants and stragglers are excluded. Passer montanus and species belonging to the following seven families: Pedicipedidae, Ardeidae, Anatidae, Rostratulidae, Charadriidae, Apodidae and Hirundinidae are not shown although some species of these families breed on Okinawa Hontô). Species that are known to breed in Yanbaru forest are indicated thus: ${ }^{\circ}$. Some subspecies endemic to the Ryukyu Archipelago but with no English name for the subspecies are described as '( $R$ subsp. $)^{\prime}$ in the 'Species' column.

Japanese lesser sparrow hawk Accipiter gularis

Barred Bottonquail Turnix suscitator

Okinawa rail Gallirallus okintazoa

Ruddy crake (R subsp.) Porzana fusca phacpyga

Common gallinule Gallimula chloropus

Amami woodcock Scolopax mira

Japanese wood pigeon Columba janthina

Ryukyu wood pigeon Columba jouyi

Oriental turtle dove (R subsp.) Streptopelia orientalis stimpsomi

Red-capped green pigeon (R subsp.) Sphenurus formosae permagnits

Ryukyu scops owl Otus elegans elegans

Collared scops owl Otus lempiji pryeri

Brown hawk owl (R subsp.) Ninox scutulata totogo

Ruddy kingfisher (R subsp.) Halcyon coromanda bangsi

Common kingfisher Alcedo atthis

Noguchi's woodpecker Sapheopipo noguchii

Japanese pigmy woodpecker (R subsp.) Dendrocopos kizuki nigrescens

Ryukyu minivet Pericrocolus dizaricatus tegimae

Brown-eared bulbul (R subsp.) Hypsipetes amaurotis pryeri

Ryukyu robin Erithacus komadori namiyei

Blue rockthrush Montocola solitarius philippensis

Japanese bush warbler (R subsp.) Cettia diphone riukiuensis

Fan-tailed warbler Cisticola juncidis

Narcissus flycatcher (R subsp.) Ficedula narcissima owstoni

Black paradise flycatcher ( $R$ subsp.) Terpsiphone atrocaudata illex

Varied tit (R subsp.) Parus varius amamii
$R$ (end)

$R$

Yanb (end) ${ }^{\circ}$

$\mathrm{R}$ (end, subsp.)

$\mathrm{R}$

A, T, O (end) ${ }^{*}$

$\mathrm{R}^{\circ}$

$\mathrm{R}$ (end)

$\mathrm{R}$ (end, susbsp.) ${ }^{\bullet}$

$\mathrm{O}$ (end, subsp.)

$\mathrm{O}$ (end, subsp.) ${ }^{\bullet}$

$\mathrm{R}$ (end, subsp.) ${ }^{\circ}$

$\mathrm{R}$ (end, subsp.) ${ }^{\circ}$

$\mathrm{R}$ (end, subsp.) ${ }^{\circ}$

$\mathrm{R}$

Yanb (end) ${ }^{\bullet}$

$\mathrm{O}$ (end, subsp.)

$\mathrm{R}$ (end subsp.) ${ }^{\circ}$

$\mathrm{R}$ (end, subsp.) ${ }^{\circ}$

Yanb (end, subsp)

$\mathrm{R}$

$\mathrm{R}$ (end, subsp.) ${ }^{\circ}$

$\mathrm{R}$

$\mathrm{R}$ (end, subsp.) ${ }^{\circ}$

O, M, Y (end, susbsp.) ${ }^{\circ}$

$\mathrm{R}$ (end, subsp.)
V

$$
\text { V }
$$




\section{Appendix (Continued)}

\begin{tabular}{|c|c|c|}
\hline Species & Distribution \& endemism* & RDB category in Japan (\& IUCN) \\
\hline $\begin{array}{l}\text { Great tit (R subsp.) Parus major okinawae } \\
\text { Japanese white eye ( } \mathrm{R} \text { subsp.) Zosteropus japonicus loochooensis } \\
\text { Jungle crow ( } \mathrm{R} \text { subsp.) Corvus macrorhynchos connectens } \\
\text { Two introduced species: Amaurornis phoenticurus and Lonchura }\end{array}$ & $\begin{array}{l}\mathrm{O} \text { (end, subsp.) } \\
\mathrm{O}^{\bullet}, \mathrm{M}, \mathrm{Y}(\text { end, subsp.) } \\
\mathrm{O}^{\circ} \mathrm{M}, \mathrm{Y} \text { (end. subsp.) } \\
\text { punctualata. }\end{array}$ & \\
\hline \multicolumn{3}{|l|}{ Reptiles } \\
\hline Japanese black-breasted leaf turtle Geoemydo japonica & $\begin{array}{l}\text { O and islands near } \mathrm{O} \\
\text { (Kerama Islands, Kume Is. (end) }\end{array}$ & $V(E)$ \\
\hline Stump-toed gecko Gehyra mutilata & $\mathrm{R}$ & \\
\hline Hokou gecko Gekko hokonensis & $\mathrm{R}$ & \\
\hline House gecko Henidactylus frenatus & $\mathrm{R}$ & \\
\hline Bowring's gecko Hemidactylus bowringii & $\mathrm{R}$ & \\
\hline Kuroiwa's ground gecko Goniurosaurus kuroiwae kuroizue & $\mathrm{O}$ (end, subsp) & $V(V)$ \\
\hline Okinawan tree lizard Japalura polygonata polygonata & N-MR (end, subsp.) & v \\
\hline Okinawa blue-tailed skink Eumeces marginatus marginatus & O (end, subsp.) & \\
\hline Barbour's blue-tailed skink Eumeces barbouri & $\mathrm{N}-\mathrm{MR}$ (end) & $\mathrm{V}$ \\
\hline Ryukyu short-legged skink Ateuchosaurus pellopleurus & $\mathrm{N}-\mathrm{MR}$ (end) & \\
\hline Green grass lizard Takydromus smaragdinus & N-MR (end) & \\
\hline Brahminy blind snake Ramphotyphlops braminus & $\mathrm{R}$ & \\
\hline Ryukyu odd-scaled snake Achalinus weneri & N-MR (end) & \\
\hline Ryukyu green snake Cyclophiops semicarinatus & N-MR (end) & \\
\hline Ryukyu odd-tooth snake Dinodon semicarinatum & $\mathrm{N}$-MR (end) & \\
\hline Pryer's keelback snake Anphiesma pryeri & N-MR (end) & \\
\hline Okinawan coral snake Hemibungarus japonicus boettgeri & N-MR (end, subsp.) & \\
\hline Habu Trimeresurus flavoviridis & N-MR (end) & \\
\hline Himehabu Ovophis okinavensis & N-MR (end) & \\
\hline \multicolumn{3}{|c|}{$\begin{array}{l}\text { Eight introduced species: Chinemys reevesii, Trachemys scriptn, Mauremys mutica, Pelodiscus sinensis, Lepidodnctylus Ingulwis, Anolis } \\
\text { corolinentsis, Elaphe taeniura and Trimeresurus mucrosquamatus. }\end{array}$} \\
\hline \multicolumn{3}{|l|}{ Amphibians } \\
\hline Anderson's crocodile newt Tylototriton andersoni & N-MR (end) & $V(E)$ \\
\hline Sword-tailed newt Cynops ensicauda & N-MR (end) & \\
\hline Hallowell's tree frog Hyla hallowellii & $\mathrm{N}-\mathrm{MR}$ (end) & \\
\hline Ryukyu brown frog Rana okinavana & N-MR (end) & \\
\hline Indian rice frog Rana limnocharis limnocharis & $\mathrm{R}$ & \\
\hline Ryukyu tip-nosed frog Rana narina & Yanb (end) & $\mathrm{V}$ \\
\hline Namie's frog Rana namiyei & Yanb (end) & $V(V)$ \\
\hline Ishikawa's frog Rana ishikawone & A, Yanb (end) & $\mathrm{E}(\mathrm{V})$ \\
\hline Holst's frog Babina holsti & $\mathrm{O}$ (end) & $\mathrm{E}(\mathrm{V})$ \\
\hline Okinawa green frog Rhacophorus viridis viridis & $O$ (end) & \\
\hline Ryukyu kajika frog Buergenin japonica & $\mathrm{R}$ & \\
\hline Ornate narrow-mouthed toad Microhyla ornata & $\mathrm{R}$ & \\
\hline Two introduced species: Rana catesbeiana and Polypedates leuco & mystax. & \\
\hline \multicolumn{3}{|l|}{ Appendix } \\
\hline \multicolumn{3}{|l|}{ Insect } \\
\hline Giant long-armed beetle Cheirotonus jambar & Yanb (end) & $\mathrm{CE}$ \\
\hline
\end{tabular}

* Localities-O: Okinawa Hontô (sometimes including small islets near O); A: Amami-Oshima Islands; T: Tokunoshima Islands; M. Miyako Islands; Y: Yaeyama Islands; R: Whole part of the Ryukyu Archipelago; N-MR: Amami Islands and Okinawa Islands, including Kume Islands and Kerama Islands.

† Species newly described in 1998 (Maeda \& Matsumura, 1998). They have been seen so far only in the NTA of Yanbaru, although one or two of them may also occur on Amami-Oshima as well (K. Maeda, pers. comm.). 